Click www.researchjournal.co.in/online/subdetail.html to purchase.

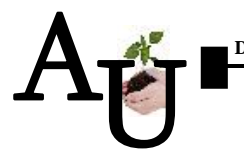

\title{
Research Article: Back yard poultry to combat protein defiency and increase income of rural families in Khammam district Telangana state
}

\section{E. JYOSHNA, J. HEMANTHA KUMAR, N. KISHORE KUMAR AND P. RAGHURAMI REDDY}

Article Chronicle :

Received :

15.07.2017;

Accepted :

30.07.2017

KeY Words:

Back yard poultry, Desi birds, Rajasri

birds, Egg

consumption, Protein

content, Protein

deficiency, Income

generation
Author for correspondence :

\section{E. JYOSHNA}

Krishi Vigyan Kendra,

Wyra, KHAMMAM

(TELANGANA.) INDIA

See end of the article for

authors' affiliations
SUMMARY : The present study was taken to assess the performance of rajasri bird in comparison with desi variety for combating protein deficiency and increase socio economic status of rural families. The study reveal that rajasri birds are more efficient than desi birds for increased protein intake and increased income.

How to cite this article : Jyoshna, E., Kumar, J. Hemantha, Kumar, N. Kishore and Reddy, P. Raghurami (2017). Back yard poultry to combat protein defiency and increase income of rural families in Khammam district Telangana state. Agric. Update, 12(TECHSEAR-5) : 1381-1383; DOI: 10.15740/HAS/AU/ 12.TECHSEAR(5)2017/1381-1383. 